\title{
What is new when it comes to acute and chronic radiation-induced dermatitis in head and neck cancer patients?
}

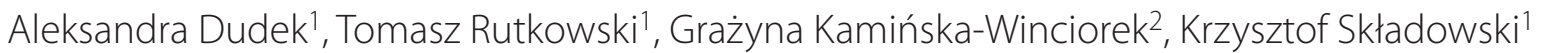 \\ 'Inpatient Department of Radiation and Clinical Oncology, Maria Sklodowska-Curie National Research Institute of Oncology, Gliwice Branch, Gliwice, \\ Poland \\ 2Department of Bone Marrow Transplantation and Oncohematology, Maria Sklodowska-Curie National Research Institute of Oncology, \\ Gliwice Branch, Gliwice, Poland
}

\begin{abstract}
Head and neck cancer is a serious clinical and social problem. Surgery and radiotherapy play the most important role in treatment and give the chance of cure. Optimal treatment of patients with head and neck cancer should provide for the maximum destruction of cancerous tissue, saving as much healthy tissue as possible. Despite this, due to radiotherapy still almost $90 \%$ of patients develop skin symptoms. It seems that the mechanism of radiodermatitis is quite clear, but studies assume that its pathogenesis is not fully understood and there is much to be clarified. Acute and chronic dermatitis caused by radiotherapy is usually diagnosed according to clinical criteria. It seems that it would be useful to have a photographic classification that would facilitate and unify the clinical evaluation. In this article we shall summarize the current knowledge about the mechanisms of formation, risk factors, clinical classifications and methods for the prevention and treatment of acute and chronic radiation dermatitis. We have included clinical photos that depict individual stages according to the clinical classification of RTOG.
\end{abstract}

NOWOTWORY J Oncol 2020; 70, 1: 9-15

\section{Key words: acute and chronic radiation-induced dermatitis}

\section{Introduction}

Head and neck cancer is a serious clinical and social problem. The major reason for poor treatment results is the advanced stage of disease at diagnosis. Surgery and radiotherapy are the main treatment options that give a chance of a complete cure [1]. Radiotherapy utilizes ionizing radiation that usually covers relatively large volumes of tissue surrounding the tumor [2]. The optimal treatment of patients with head and neck cancer involves a compromise between destroying as much cancerous tissue as possible, and saving as much healthy tissue as possible [3]. Radiotherapy should be carried out with the use of modern technologies, such as conformal 3D radiation, and, in particular, intensity-modulated radiation therapy (IMRT) [1]. This method allows for a significant reduction in tissue volume subject to the high radiation dose, and in the intensity of acute radiation-related reactions of these tissues. Despite this, still almost $90 \%$ of patients develop skin symptoms after radiotherapy [4]. Radiation-induced reactions can be divided into early and late as regards the time of their appearance in the relation to radiotherapy. Acute (early) ones appear during radiotherapy and usually disappear a few weeks after the completion of the treatment. Late reactions appear months after radiotherapy and may leave chronic results [5]. In turn, as far as the extent of radiation is concerned, reactions can be local or generalized [2, 3].

\section{Pathogenesis}

According to the Michalowski and Wheldon classification, proliferative tissues can be divided into "hierarchical"and "flexible", 
and consequently, the course of radiation injury differs in these two groups [6]. The skin belongs to hierarchical tissues and is made of mature cells, maturing cells and stem cells. Radiotherapy causes cells, $70 \%$ of which is composed of water, to become ionized [6]. Hydrolysis of water and the formation of free radicals, be it direct or indirect, causes breaks in the DNA and cell death. The lethal effect mainly pertains to stem cells and, to some extent, to maturing cells [3]. Consequently, the balance between normal cell production at skin's basal layer and cell destruction at skin surface is disrupted [3]. The radiation-induced skin reaction reflects the degree of cell damage. Its intensity depends on the radiation dose, and increases with the number of stem cells that die. The first phase, transient erythema, may occur 24 hours after radiotherapy, with vessels becoming wider and more permeable [5]. Inflammatory cytokines, prostaglandins, and many other mediators are secreted $[3,5]$. This inflammatory reaction causes the development of a secondary erythematous response. Immune cells, keratinocytes, fibroblasts and other cells are stimulated. Subsequent radiation doses create a vicious circle and correlate with the degree of radiodermatitis [7]. In the next phase, dry exfoliation usually occurs, which results from the disturbed balance between the division of new cells and the exfoliation of the old ones. In the final stage, stem cells are lacking and the skin has no material from which to rebuild individual layers. Wet exfoliation and exudates occur [7]. The inflammation that started in the epidermis after the beginning of irradiation lasts for months, and even years. Inflammatory cytokines are secreted, including interleukin IL-1 a, IL-1 $\beta$, tumor necrosis factor TNF- $a$, TGF- $\beta, I L-6, I L-8$ [7]. The secretion of TGF- $\beta$, which is a central mediator of fibrogenesis, increases following the exposure to ionizing radiation, and it is proportional to the radiation dose delivered $[8,9]$. Huang and Glick summarize the knowledge about major genes and polymorphisms, and delineate the role of TGF- $\beta$ as a peptide protein gene associated with an immune response that plays an important role in both early and late dermatitis [10]. Studies using the rat and mice model show that those less equipped with this protein are not as sensitive to radiotherapy as wild rats $[9,11]$.

Despite this knowledge, the studies at the National Jewish Health Biological Resource Center assumed that pathogenesis of radiodermatitis is not fully understood. Using mouse models in their project, the researchers at the Center discovered that the transient receptor potential melastatin 2 (TRPM2) ion channel plays a major role in developing radiation injury. They suggest that TRPM2 may be a potential target for a systemic medicine which would inhibit this channel and reduce the severity of radiodermatitis [12]. However, other researchers who have also used mouse models say that plasminogen plays a major role in the development of radiation injury. Among other things, it participates in the activation of many inflammatory factors, such as TGF- $\beta$. Fallah et al. used tranexamic acid, postulating that inhibiting plasminogen could be used as treatment or as a preventive option in the future [13]. The pathogenesis of bio-radiation dermatitis differs from that associated with radiotherapy alone. Inhibition of the EGFR pathway results in a disruption of physiological processes associated with the migration and proliferation process, and the development of inflammation in the skin. The type of response depends on the degree of interaction between the inhibitor of EGFR pathway and radiotherapy [14]. The multitude of reports on factors that may be involved in the development of acute and chronic radiation-induced dermatitis is certainly attributable to the fact that many studies are still needed to find out the actual pathogenesis of this process.

\section{Risk factors}

The risk factors associated with the development of radiodermatitis can be divided into patient- and treatment-related [3, 7], where the letter include the type and energy of irradiation, the dose per fraction, the duration of treatment, and the total radiation dose [3]. An additional factor associated with the treatment may be concurrent chemotherapy. Researchers have shown that chemotherapy improves the therapeutic effect [15-17], but also increases the intensity of radiodermatitis [18]. EGFR inhibitor - cetuximab given during radiotherapy increases the intensity more seriously compared to radiotherapy alone [14]. Concomitant diseases, a patient's age, past injuries and surgeries in the irradiated area should be considered as the main patient-related factors [3]. Patients with genetic disorders, such as ataxia-telangiectasia or the Nijmegen syndrome, show a genetically determined susceptibility to the development of radiation damage. Consequently, their normal cells are hypersensitive to the radiation-related damage [3].

The neoplastic tissue itself is a constant factor affecting the severity and development of radiodermatitis. It secretes factors that increase the number of cells that divide both cancerous and healthy tissues [3]. Undoubtedly, the study conducted by Huang and Glick shows how many risk factors are associated with human genetic material and how many factors affect the development of radiodermatitis [10]. Kawamura et al. present a new radiation dermatitis scoring system. The results of their study show that radiation dose, concurrent chemotherapy, age and body mass index (BMI) have a predictive significance. On this basis, they constructed a score system combining the above parameters [18]. Apart from this, there are no other commonly used score systems that allow predicting the risk and intensity of acute and late skin reactions in patient before radiotherapy.

\section{Clinical classification}

In clinical practice, various clinical scales are applied in the assessment of acute and chronic radiodermatitis. The Radiation Therapy Oncology Group and the European Organization for Research and Treatment of Cancer (RTOG/EORTC), Common Terminology Criteria for Adverse Events (CTCAE), and the Late 
Effects Normal Tissue Task Force-Subjective, Objective, Management, Analytic (LENTSOMA) scales are used most often [19]. RTOG/EORTC scale is dedicated to assessing early and late post-radiation reactions (Tab. I) [20].

LENTSOMA scores only late reactions [4]. In turn, CTCAE does not describe the late effect, but only its acute phase [19] (Tab. II).

Generally, RTOG scale refers to various tissues and organs. At grade 0 , no skin reactions are observed. Reactions of different intensities are scored between grades I to IV, with death due to dermatitis at grade $V$ [20]. In our review, we include figures presenting the individual grades in line with the RTOG classification.

At grade I, erythema of moderate intensity is observed. Hair loss and dry exfoliation may also occur (Fig. 1) [20]. At grade II, usually, tender or bright erythema is visible with moist desquamation. This is accompanied by moderate swelling (Fig. 2) [20]. At grade III, erythema is accompanied by swelling and moist exfoliation, which includes areas outside the skinfolds (Fig. 3) [20]. Grade IV is characterized by ulceration, bleeding

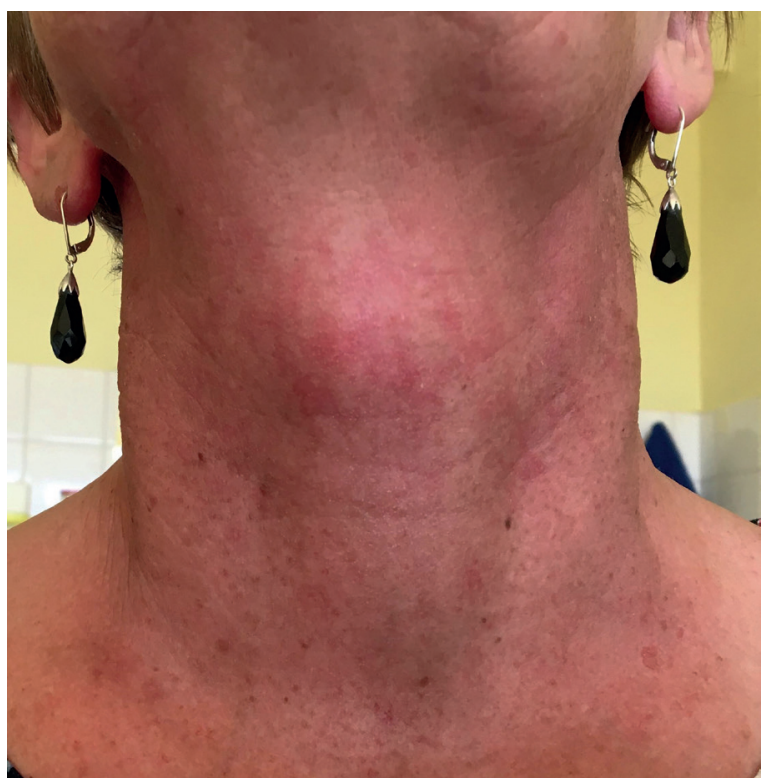

Figure 1. Follicular dull erythema with epilation and red dermographism in the course of acute radiodermatitis, RTOG/EORTC grade I

Table I. Early and late post-radiation reactions

\begin{tabular}{|c|c|c|c|c|}
\hline & Grade I & Grade II & Grade III & Grade IV \\
\hline $\begin{array}{l}\text { Acute } \\
\text { radiodermatitis }\end{array}$ & $\begin{array}{l}\text { follicular, faint or dull } \\
\text { erythema, epilation, dry } \\
\text { desquamation, decrease } \\
\text { sweating }\end{array}$ & $\begin{array}{l}\text { tender or bright erythema, } \\
\text { patchy moist desquamation, } \\
\text { moderate edema }\end{array}$ & $\begin{array}{l}\text { confluent, moist } \\
\text { desquamation other then } \\
\text { skin folds, pitting edema }\end{array}$ & $\begin{array}{l}\text { ulceration, hemorrhage, } \\
\text { necrosis }\end{array}$ \\
\hline $\begin{array}{l}\text { Chronic } \\
\text { radiodermatitis }\end{array}$ & $\begin{array}{l}\text { slight atrophy, pigmentation } \\
\text { change, some hair loss }\end{array}$ & $\begin{array}{l}\text { patchy atrophy, moderate } \\
\text { teleangiectasia, total hair loss }\end{array}$ & $\begin{array}{l}\text { marked atrophy, gross } \\
\text { teleangiectasia }\end{array}$ & ulceration \\
\hline
\end{tabular}

Table II. Late post-radiation reactions - proposed modifications

\begin{tabular}{|c|c|c|c|c|}
\hline & Grade I & Grade II & Grade III & Grade IV \\
\hline $\begin{array}{l}\mathrm{NCl}-\mathrm{CTCAE} \vee 4.03 \\
\text { radiation dermatitis }\end{array}$ & $\begin{array}{l}\text { faint erythema or dry } \\
\text { desquamation }\end{array}$ & $\begin{array}{l}\text { moderate to brisk erythema; } \\
\text { patchy moist desquamation, } \\
\text { mostly confined to skin folds } \\
\text { and creases; moderate edema }\end{array}$ & $\begin{array}{l}\text { moist desquamation in } \\
\text { areas other than skin folds and } \\
\text { creases; bleeding induced by } \\
\text { minor trauma or abrasion }\end{array}$ & $\begin{array}{l}\text { life-threatening } \\
\text { consequences; skin necrosis or } \\
\text { ulceration of full-thickness dermis; } \\
\text { spontaneous bleeding from } \\
\text { involved site; skin graft indicated }\end{array}$ \\
\hline $\begin{array}{l}\text { Proposed } \\
\text { modifications }\end{array}$ & $\begin{array}{l}\text { faint erythema or dry } \\
\text { desquamation }\end{array}$ & $\begin{array}{l}\text { moderate to brisk erythema } \\
\text { and/or dry desquamation; } \\
\text { patchy moist desquamation, } \\
\text { or nonhemorrhagic crusts } \\
\text { mostly confined to skin folds } \\
\text { and creases }\end{array}$ & $\begin{array}{l}\text { moist desquamation or } \\
\text { hemorrhagic crusts; } \\
\text { nonhemorrhagic } \\
\text { crusts other than in } \\
\text { skin folds and mostly } \\
\text { confined to skin folds and } \\
\text { creases; bleeding induced } \\
\text { by minor trauma or abrasion; } \\
\text { superinfection requiring } \\
\text { oral antibiotics }\end{array}$ & $\begin{array}{l}\text { life-threatening } \\
\text { consequences; extensive } \\
\text { confluent hemorrhagic crusts } \\
\text { or ulceration ( }>50 \% \text { of involved } \\
\text { field); extensive spontaneous } \\
\text { bleeding from involved site } \\
\text { (>40\% of the involved site); } \\
\text { skin necrosis or ulceration of } \\
\text { full-thickness dermis or any size } \\
\text { ulcer with extensive destruction, } \\
\text { tissue necrosis or damage to } \\
\text { muscle, bone or supporting } \\
\text { structures with or without full- } \\
\text { thickness skin loss; skin graft } \\
\text { indicated; ulceration associated } \\
\text { with extensive superinfection } \\
\text { with i.v. antibiotics indicated }\end{array}$ \\
\hline
\end{tabular}




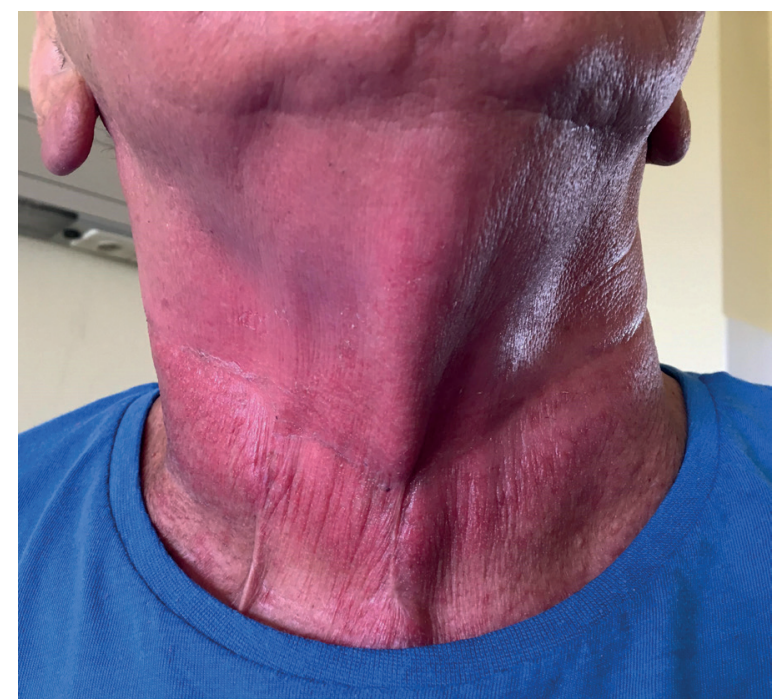

Figure 2. Tender and bright erythema with moderate edema-within the irradiated area in the course of acute radiodermatitis, RTOG/EORTC grade II

and necrosis [20]. In contrast to the acute cutaneous reaction after radiation therapy, chronic dermatitis occurs not earlier than 90 days from completing radiotherapy and may develop even a few years after irradiation [5]. It is clinically characterized by moderate (Fig. 4) to severe atrophy (Fig. 7) accompanied by telangiectasia (Fig. 4-7), as well as ulceration (Fig. 7) (grade IV) [20]. RTOG, CTCAE and LENTSOMA are descriptive scales, with a risk of subjective evaluation and classification of acute and chronic radiation dermatitis [21]. Zenda et al. provide an atlas of radiodermatitis with pictures showing grades from I to IV according to CTCAE. A photographic classification could be useful in supporting and unifying the clinical one [21]. Acute and chronic dermatitis caused by radiotherapy is usually diagnosed based

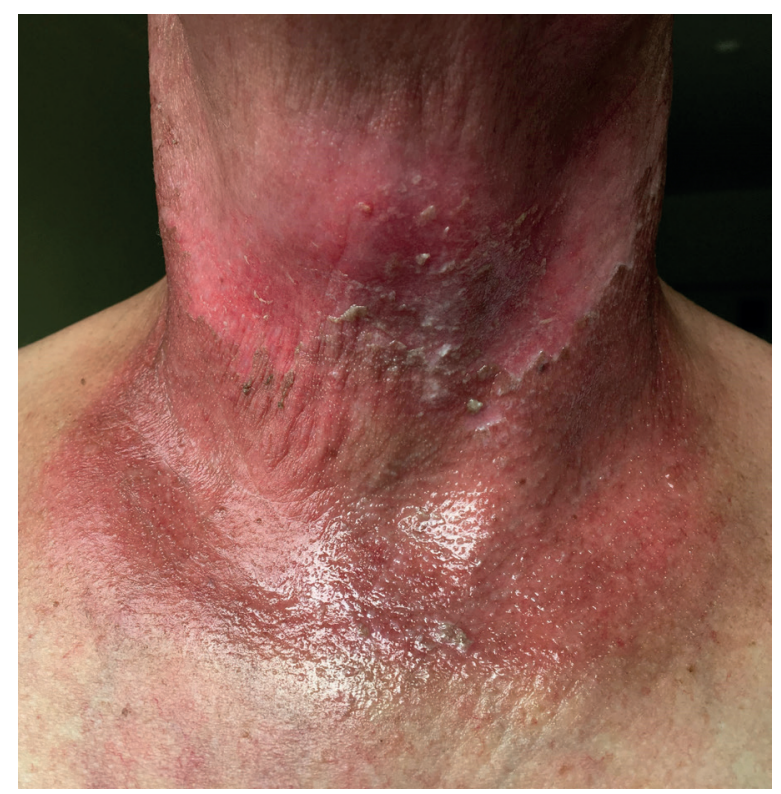

Figure 3. Sharp demarcated, exacerbated erythema accompanied by swelling and moist exfoliation, expanding to non-irradiated neighbouring areas in the course of acute radiodermatitis, RTOG/EORTC grade III

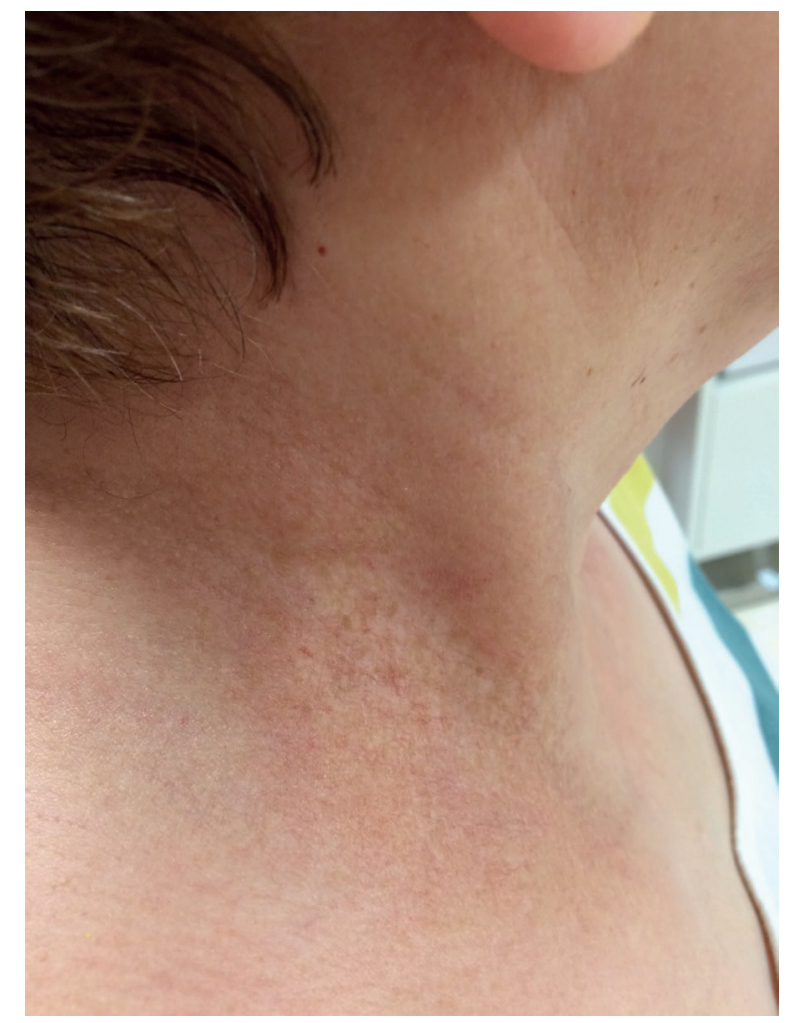

Figure 4. Slight atrophy, poikilodermic pigmentation (mainly depigmentation) with permanent hair loss and several thin telangiectasias in the course of chronic radiodermatitis, RTOG/EORTC grade I

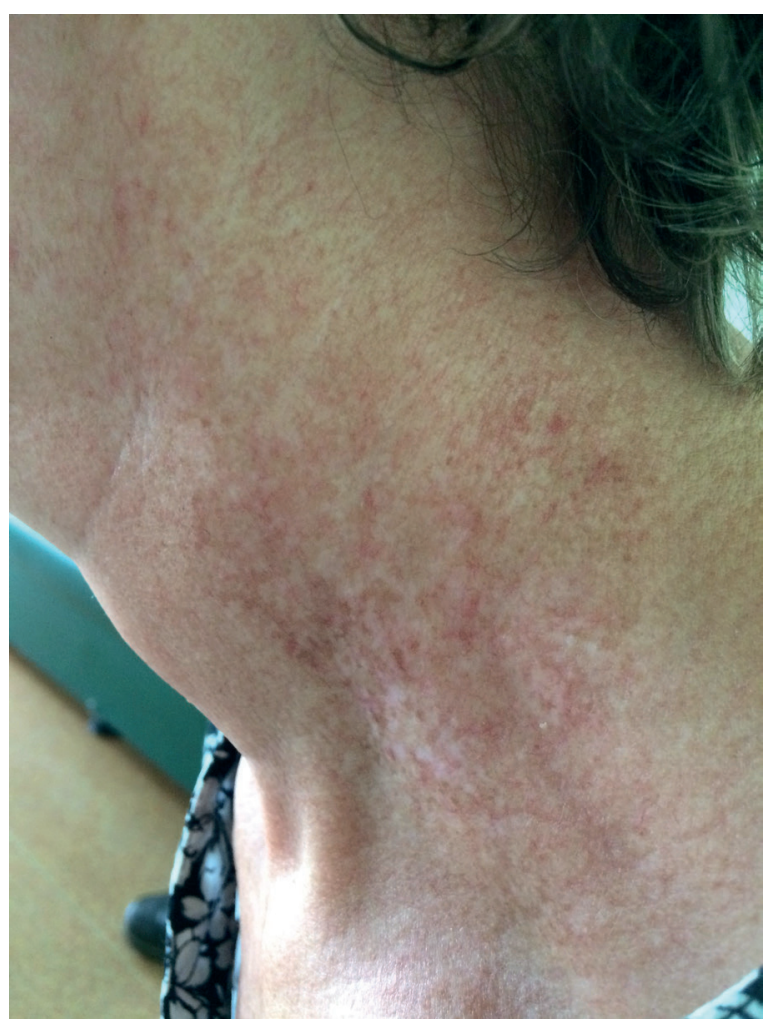

Figure 5. Patchy atrophy areas with thin, moderate telangiectasias accompanied by total hair loss and skin discoloration (depigmented and brownish spots) in the course of chronic radiodermatitis, RTOG/ EORTC grade II 


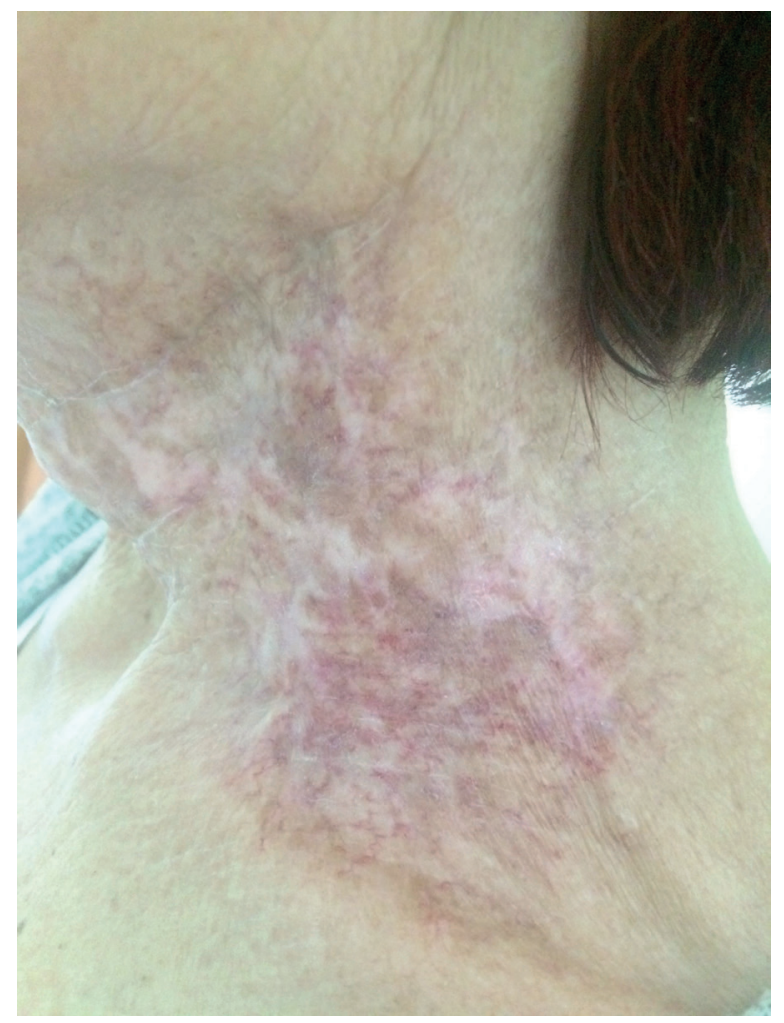

Figure 6. Marked skin atrophy presented as multiple whitish scarred lines with multiple gross telangiectasias in the course of chronic radiodermatits, RTOG/EORTC grade III

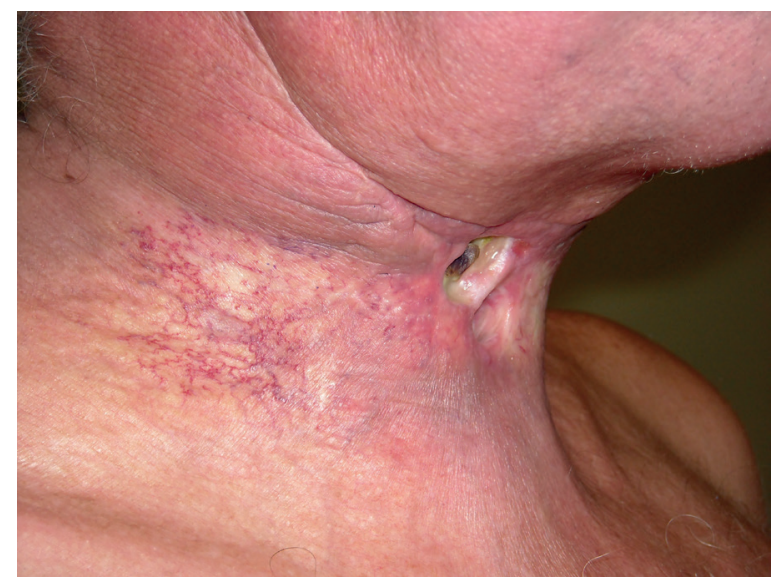

Figure 7. Advanced atrophy with multiple gross telangiectasias and desquamation of the skin. Diffused white atrophy with multiple thick telangiectasias also observed. Thinning of the skin of epidermis also seen in the course of chronic radiodermatitis, RTOG/EORTC grade IV

on the above-mentioned clinical criteria. CTCAE 4.0 appears to be the most commonly used scale during clinical assessment, but it is not a unified, unambiguous system for the assessment of post-radiation reactions [19]. It is worth mentioning that the combined treatment involving concomitant radiotherapy and EGFR inhibitor may result in reaction called bio-radiation dermatitis [22]. This type of reaction has a different pathogenesis and clinical characteristics [14]. Bernier et al. propose guidelines on the classification and treatment of bio-radiation dermatitis.
These would help clinicians to properly assess and manage it. The treatment could be optimized, and there would be a greater chance of a good clinical outcome [14, 23]. Table II shows the changes proposed by Bernier et al. in relation to CTCEA. In grades $\|-I V$, the change in type and extent of crusting can be observed. Infections may influence the intensity of bio-radiation and therefore appropriate local or systemic treatment should be considered (Tab. II) [14]. The extent of spontaneous bleeding is concerned at grade IV (Tab. II) [14].

\section{Prevention and treatment}

The latest recommendation on prevention and treatment was published in 2013 by the Multinational Association of Supportive Care in Cancer (MASCC) Skin Toxicity Study Group [19], and showed that randomized studies have confirmed that skin hygiene with the use of water, with or without gentle soap, and the use of antiperspirants is recommended. A positive effect of using topical glucocorticosteroids has also been shown [19].

In 2015 O'Donnovan carried out an anonymous online survey in Europe and in the United States [24]. It turned out that there is a large discrepancy between the clinical management, prevention and treatment of acute radiodermatitis, and what has been confirmed in scientific studies. Many of the commercially available products have no scientific support [24].

In 2017 Lucey et al. began another such study in the United States. They conclude that there is a considerably wide variety in the prevention and treatment of acute radiodermatitis [25]. At the same time, this type of research shows that, in fact, no recommendations are available yet. However, since clinical experience shows that this process yields some effects, it requires confirmatory research. Lucey et al. show that aloe vera, gentle soap, and topical glucocorticosteroids are most commonly used for the prevention of acute radiation injury [25]. When it comes to treatment, it is correlated with the degree of the development of radiodermatitis [25]. Dry desquamation is mostly treated with emollients and aloe vera [25]. For grade II and III, silver sulfadiazine cream is most commonly used. A comparison of procedures at different centers in the country showed that the procedures result from observation in $89 \%$ of cases, and only in 51,4\% from scientifically confirmed studies [25]. There is evidently a need to carry out tests confirming the effectiveness of individual intervention. In 2018 a randomized Radiotherapy Related Skin Toxicity (RAREST-01) study commenced [26]. It compares standard care and Mepitel Film (gentle, transparent, breathable dressings) in patients with locally advanced squamous-cell carcinoma of the head and neck receiving radiotherapy or radiochemotherapy [26]. One of the surveys done in China confirmed the effectiveness of Mepitel Film dressings and it decreases acute radiation injury in head and neck cancer patients [27].

At the same time, the third phase of the study protocol of J-SUPPORT 1602 (TOPICS study) began, comparing topical glucocorticosteroids with placebo as prevention of radiation 
injury [28]. Zhang et al. used red light therapy and it turned out that such an intervention may accelerate wound healing, reduce pain, and improve the patient's life [29]. Ferreira et al. published a review of 13 randomized studies. Intervention with trolamine, aloe vera, allantoin, Lianbai liquid (Chinese remedy), sucralfate, Na-sucrose octasulfate, olive oil, hyaluronic acid, and dexpanthenol did not show any benefits in prevention and treatment of radiation injury [30]. At the same time, there was no difference between the control group using institution routine, aqueous cream, mild soap, water thermal gel, placebo, and no intervention [30]. Regarding bio-radiation dermatitis, Bonomo et al. confirmed the effectiveness of calcium dressing for moist exfoliation [22]. Side effects like radiodermatitis which is particularly visible may significantly impair the quality of life. Non-pharmacological recommendations and patient education should not be forgotten [31].

It is very important to minimize the risk of infection using an appropriate standard of hygiene and choose the right cosmetics and cleaning products that are clinically tested and adapted to this group of patients. In addition, patients should remember about photoprotection [31]. Experts believe that in the interests of patient's well-being, the use of deodorants and non-irritating perfumes can be part of daily routine [31]. It is very important to conduct regular dermatological follow-ups due to the fact that chronic radiation dermatitis predisposes patients to secondary malignant tumors [32, 33].

\section{Conclusions}

At this time, there is a lot of reports on factors that may be involved in the pathogenesis of acute and chronic radiodermatitis. Further studies are still needed to confirm and find out the actual nature of the pathogenesis of this process. Clinical assessment is carried out using various clinical scales. There is no one unified system which would make our assessments uniform, and thanks to which we could subsequently proceed with treatment. There is a good chance that the photographic atlas presenting the selected grade of acute and chronic radiodermatitis may unify the clinical evaluation.

Currently, apart from one study, there are no specific prognostic factors and predictors that could indicate the dynamics and severity of acute dermatitis caused by radiotherapy or prognostic factors related to the late reaction of skin. Genetic susceptibility testing and the determination of the final pathogenesis pathway in the future may bring the target for treatment and prevention. Currently, the last recommendations come from 2013; they were published by MASCC Skin Toxicity Study Group [17]. By 2019, no new recommendations have been issued, and the clinics today are based on observation in $89 \%$ of cases and only in $51.4 \%$ on clinically confirmed results [23].

Appropriate assessment of the severity of acute and chronic radiation induced skin injury makes it possible to decide how to proceed with patients, especially with such groups for which the cosmetic effect has special importance for personal, social and professional reasons.

Conflict of interest: none declared

\section{Grażyna Kamińska-Winciorek}

Maria Sklodowska-Curie National Research Institute of Oncology, Gliwice Branch

Department of Bone Marrow Transplantation and Oncohematology ul. Wybrzeże Armii Krajowej 15

44-101 Gliwice, Poland

e-mail: grazyna.kaminskawinciorek@gmail.com

Received: 4 Nov 2019

Accepted: 13 Jan 2020

\section{References}

1. Wierzbicka M, Bień S, Osuch-Wójcikiewicz E, et al. The recommendations of diagnostic and therapeutic in the treatment of head and neck cancers. Pol. Przeglad Otorynolaryngol. ; 2011: 17-43.

2. Biedka M, Dutsch-Wicherek M. Side effects of postoperative radiotherapy in patient with laryngeal cancer receiving immunosuppressive drugs after renal transplant. Otorynolaryngologia. 2015; 14(2): 108-116.

3. Ziółkowska E, Biedka M, Windorbska W. Odczyn popromienny u chorych na raka regionu głowy i szyi: mechanizmy i konsekwencje. Otorynolaryngologia. 2011; 10(4): 147-153.

4. Michalewska J. Odczyny popromienne w radioterapii oraz popromienne zapalenie skóry. Letters in Oncology Science. 2017; 14(4): 104-109, doi: 10.21641/los.14.4.41

5. Hegedus F, Mathew LM, Schwartz RA. Radiation dermatitis: an overview. Int J Dermatol. 2017; 56(9): 909-914, doi: 10.1111/ijd.13371, indexed in Pubmed: 27496623.

6. Wheldon TE, Michalowski AS, Kirk J.The effect of irradiation on function in self-renewing normal tissues with differing proliferative organisation. Br J Radiol. 1982; 55(658): 759-766, doi: 10.1259/0007-1285-55-658-759.

7. Robijns J, Laubach HJ. Acute and chronic radiodermatitis. Journal of the Egyptian Women's Dermatologic Society. 2018; 15(1): 2-9, doi: 10.1097/01.ewx.0000529960.52517.4c

8. Biernacka A, Dobaczewski M, Frangogiannis NG. TGF- $\beta$ signaling in fibrosis. Growth Factors. 2011; 29(5): 196-202, doi: 10.3109/08977194.2011.595714, indexed in Pubmed: 21740331.

9. de Andrade CB, Ramos IP, de Moraes AC, et al. Radiotherapy-Induced Skin Reactions Induce Fibrosis Mediated by TGF- $\beta 1$ Cytokine. Dose Response. 2017; 15(2): 1559325817705019, doi: 10.1177/1559325817705019, indexed in Pubmed: 28507463.

10. Huang A, Glick SA. Genetic susceptibility to cutaneous radiation injury. Arch Dermatol Res. 2017; 309(1): 1-10, doi: 10.1007/s00403-016-1702-3, indexed in Pubmed: 27878387.

11. Flanders K, Major C, Arabshahi A, et al. Interference with Transforming Growth Factor- $\beta$ / Smad3 Signaling Results in Accelerated Healing of Wounds in Previously Irradiated Skin. The American Journal of Pathology. 2003; 163(6): 2247-2257, doi: 10.1016/s0002-9440(10)63582-1.

12. Perraud AL, Rao DM, Kosmacek EA, et al. The ion channel, TRPM2, contributes to the pathogenesis of radiodermatitis. Radiat Environ Biophys. 2019; 58(1): 89-98, doi: 10.1007/s00411-018-0769-y, indexed in Pubmed: 30483886.

13. Fallah $\mathrm{M}$, Shen $\mathrm{Y}$, Brodén J, et al. Plasminogen activation is required for the development of radiation-induced dermatitis. Cell Death Dis. 2018; 9(11): 1051, doi: 10.1038/s41419-018-1106-8, indexed in Pubmed: 30323258.

14. Bernier J, Russi EG, Homey B, et al. Management of radiation dermatitis in patients receiving cetuximab and radiotherapy for locally advanced squamous cell carcinoma of the head and neck: proposals for a revised grading system and consensus management guidelines. Ann Oncol. 2011;22(10): 2191-2200, doi: 10.1093/annonc/mdr139, indexed in Pubmed: 21606209.

15. Brizel DM, Albers ME, Fisher SR, et al. Hyperfractionated irradiation with or without concurrent chemotherapy for locally advanced head and neck cancer. N Engl J Med. 1998; 338(25): 1798-1804, doi: 10.1056/ NEJM199806183382503, indexed in Pubmed: 9632446.

16. Pignon JP, le Maître A, Maillard E, et al. MACH-NC Collaborative Group. Meta-analysis of chemotherapy in head and neck cancer (MACH-NC): 
an update on 93 randomised trials and 17,346 patients. Radiother Oncol. 2009; 92(1): 4-14, doi: 10.1016/j.radonc.2009.04.014, indexed in Pubmed: 19446902.

17. Tobias JS, Monson K, Gupta N, et al. UK Head and Neck Cancer Trialists' Group. Chemoradiotherapy for locally advanced head and neck cancer: 10-year follow-up of the UK Head and Neck (UKHAN1) trial. Lancet Oncol. 2010; 11(1): 66-74, doi: 10.1016/\$1470-2045(09)70306-7, indexed in Pubmed: 19875337.

18. Kawamura $\mathrm{M}$, Yoshimura $\mathrm{M}$, Asada $\mathrm{H}$, et al. A scoring system predicting acute radiation dermatitis in patients with head and neck cancer treated with intensity-modulated radiotherapy. Radiat Oncol. 2019; 14(1): 14, doi: 10.1186/s13014-019-1215-2, indexed in Pubmed: 30665451.

19. Wong RKS, Bensadoun RJ, Boers-Doets CB, et al. Clinical practice guidelines for the prevention and treatment of acute and late radiation reactions from the MASCC Skin Toxicity Study Group. Support Care Cancer. 2013; 21(10): 2933-2948, doi: 10.1007/s00520-013-1896-2, indexed in Pubmed: 23942595.

20. Radiation Therapy Oncology Group (RTOG). RTOG/EORTC Late Radiation Morbidity Scoring Schema. https://www.rtog.org/Research Associates/AdverseEventReporting/RTOGEORTCLateRadiationMorbidity ScoringSchema.aspx..

21. Zenda $\mathrm{S}, \mathrm{Ota} \mathrm{Y}$, Tachibana $\mathrm{H}$, et al. A prospective picture collection study for a grading atlas of radiation dermatitis for clinical trials in head-and-neck cancer patients. J Radiat Res. 2016; 57(3): 301-306, doi: 10.1093/ jrr/rrv092, indexed in Pubmed: 26850926.

22. Bonomo P, Desideri I, Loi M, et al. Management of severe bio-radiation dermatitis induced by radiotherapy and cetuximab in patients with head and neck cancer: emphasizing the role of calcium alginate dressings. Support Care Cancer. 2019; 27(8): 2957-2967, doi: 10.1007/ s00520-018-4606-2, indexed in Pubmed: 30569265.

23. Russi EG, Bensadoun RJ, Merlano MC, et al. Bio-radiation dermatitis: the need of a new grading: in regard to Bernier et al: Ann Oncol 2011; 22(10): 2191-2200. Ann Oncol. 2013; 24(9): 2463-2465, doi: 10.1093/ annonc/mdt281, indexed in Pubmed: 23897703.

24. O'Donovan A, Coleman M, Harris R, et al. Prophylaxis and management of acute radiation-induced skin toxicity: a survey of practice across Europe and the USA. Eur J Cancer Care (Engl). 2015; 24(3): 425-435, doi: 10.1111/ecc.12213, indexed in Pubmed: 24986477.
25. Lucey $P$, Zouzias $C$, Franco L, et al. Practice patterns for the prophylaxis and treatment of acute radiation dermatitis in the United States. Support Care Cancer. 2017; 25(9): 2857-2862, doi: 10.1007/s00520017-3701-0, indexed in Pubmed: 28411323.

26. Narvaez C, Doemer C, Idel C, et al. Radiotherapy related skin toxicity (RAREST-01): Mepitel $^{\oplus}$ film versus standard care in patients with locally advanced head-and-neck cancer. BMC Cancer. 2018; 18(1): 197, doi: 10.1186/s12885-018-4119-x, indexed in Pubmed: 29454311.

27. Wooding $H$, Yan J, Yuan L, et al. The effect of Mepitel Film on acute radiation-induced skin reactions in head and neck cancer patients: a feasibility study. Br J Radiol. 2018; 91(1081): 20170298, doi: 10.1259/ bjr.20170298, indexed in Pubmed: 29072852.

28. Zenda S, Yamaguchi T, Yokota T, et al. Topical steroid versus placebo for the prevention of radiation dermatitis in head and neck cancer patients receiving chemoradiotherapy: the study protocol of J-SUPPORT 1602 (TOPICS study), a randomized double-blinded phase 3 trial. BMC Cancer. 2018; 18(1): 873, doi: 10.1186/s12885-018-4763-1, indexed in Pubmed: 30189840.

29. Zhang X, Li H, Li Q, et al. Application of red light phototherapy in the treatment of radioactive dermatitis in patients with head and neck cancer. World J Surg Oncol. 2018; 16: 222.

30. Ferreira EB, Vasques $\mathrm{Cl}$, Gadia R, et al. Topical interventions to prevent acute radiation dermatitis in head and neck cancer patients: a systematic review. Support Care Cancer. 2017; 25(3): 1001-1011, doi: 10.1007/ s00520-016-3521-7, indexed in Pubmed: 27957620.

31. Bensadoun RJ, Humbert P, Krutman J, et al. Daily baseline skin care in the prevention, treatment, and supportive care of skin toxicity in oncology patients: recommendations from a multinational expert panel. Cancer Manag Res. 2013; 5: 401-408, doi: 10.2147/CMAR.S52256, indexed in Pubmed: 24353440.

32. Chapter 8. In:Wells M, MacBride S. ed. Radiation skin reactions. Churchill Livingstone, Elsevier, London 2003.

33. Mendelsohn FA, Divino CM, Reis ED, et al. Wound care after radiation therapy. Adv Skin Wound Care. 2002; 15(5): 216-224, doi: 10.1097/00129334-200209000-00007, indexed in Pubmed: 12368711. 